DOI: https:// 10.15407/kvt196.02.059

UDC 577.169; 616.1-616.7

SHLYKOV V.V. ${ }^{1}, \mathrm{PhD}$, Associate professor

Department of Biomedical Engineering

e-mail: v.shlykov@kpi.ua

MAKSYMENKO V.B. ${ }^{2}$, DSc (Medicine), Professor

Deputy Director for Research

e-mail: maksymenko.vitaliy@gmail.com

${ }^{1}$ National Technical University of Ukraine

"Igor Sikorsky Kyiv Polytechnic Institute"

37, Peremogy av., Kyiv, Ukraine, 03056

${ }^{2}$ Amosov National Institute of Cardiovascular Surgery

6, Amosov st., Kyiv, Ukraine, 03038

\title{
THE METHOD OF DETERMINING CONDUCTIBILITY FOR CORONARY VESSELS BY TERMOGRAPHY
}

\begin{abstract}
Introduction. The character of the distribution of temperature in the heart is determined by the process of heat exchange between the myocardium and coronary vessels, as well as the state of microhemodynamics of the coronary vessels of the heart. For quantitative estimation of changes in temperature distribution on the surface of the heart, the algorithm for calculating a quantitative criterion, that may be an objective marker for effective protection of the heart and brain, is proposed. The method of determining the conductibity of coronary vessels is implemented on the basis of the algorithm for determining the thermal contours, calculated from the gradients of the temperature field on the image of the heart in the infrared spectrum. The improvement of the previously developed method for determining the thermal contours on the basis of Canny's algorithm consists of the transition from qualitative to quantitative assessment of the rate of change in temperature on the surface of the myocardium.

The purpose of this study is to evaluate the conductibity of coronary vessels for the study of blood flow in the surface layer of the myocardium during warming up and cooling of the heart in conditions of cardiopulmonary bypass.

Results. The numerical value of the quantitative criterion obtained is calculated by determining the difference in temperature between the blood and the myocardium, calculated as the difference between the geometric areas under the temperature distribution curves in the temperature field equation for the constant and the current fluxing temperature. The contouring method for determining the conductibity of coronary vessels allows to select areas on the surface of the myocardium, in which the change in temperature significantly lags behind the average temperature on the surface during warming or cooling of the heart, which indirectly allows evaluating the state of small coronary vessels in the myocardium.
\end{abstract}


Conclusions. The method for determining the conductivity of coronary vessels for the study of blood flow in the surface layer of the myocardium is proposed, which allowed to allocation contours of sites on the surface of the myocardium with uneven distribution of temperature during warming up and cooling of the heart. Scientific novelty of the method consists of the allocation of thermal contours of sites in which the temperature change significantly lags behind the average temperature on the surface during warming up or cooling of the heart.

Keywords: mathematical modelling, the algorithm of detector Canny, heart temperature, temperature profiles, hypothermia, hyperthermia, cardiopulmonary bypass.

\section{INTRODUCTION}

During controlled cooling and warming on thermography images, the uneven distribution of temperature in tissues is become visible. In inflammatory processes in the myocardium, areas of hyperthermia that correspond to the area of infiltration, that indicate a difference in temperature with adjacent tissues are determined. In chronic inflammation, the temperature difference is $0,7-1^{\circ} \mathrm{C}$, with acute illness $1-1,5^{\circ} \mathrm{C}$, and in the destructive process reaches $1,5-2^{\circ} \mathrm{C}[1,2]$. When the blood temperature changes in the circulatory circuit, the body temperature of the patient also changes. Moreover, the temperature difference between the blood in the contour and the patient's body should not differ by more than $15^{\circ} \mathrm{C}[3,4]$.

The temperature field recorded by the thermographic system reflects the unique morphological and biophysical characteristics of the myocardium [19]. The main reason for violations of local temperature in the heart is the microcirculation in the tissues of the myocardium due to inflammatory processes. The regulation of temperature in the myocardium is mainly carried out by changing the lumen of the coronary vessels $[20,21]$. When cooling the heart, there is a slowing of blood flow and narrowing of the surface vessels. In another situation, with warming the heart, blood flow is redistributed to the surface of the vessels, which facilitates the removal of heat into the external operating field. In this case there is a so-called transverse temperature gradient that is the difference in temperature between the surface and deep layers of tissue of the myocardium.

\section{TASKS OF THE RESEARCH}

Analytical studies of temperature distribution on the surface of the heart are based on the developed model of the system of myocardium- coronary vessels $[5,6]$, the model of heat exchange for the process of cooling the blood and heart, and the model of heat flux propagation in the myocardium in the process of hypothermia and hyperthermia [7,8], for calculating which used the methods of theoretical and mathematical physics (solving the boundary value of thermal conductibility) with the involvement of experimental data on the distribution of thermal fields in areas of temperature anomalies on the surface of the heart and methods of the statistical analysis and processing of experimental data [22-24].

The development of the method of contouring temperature inhomogeneities for determining the conductivity of coronary vessels on the basis of the algorithm of detector Canny is a promising task for the implementation of information technology for non-invasive control of heart temperature during conduction of thermography studies in cardiology. 
The introduction of the method for assessing the conductibility of coronary vessels in cardiac surgery will allow in the long run non-invasively control the blood temperature in blood vessels and determine the efficiency of the operation of distal septum vessels after coronary bypass surgery in conditions of controlled cooling and warming during cardiopulmonary bypass.

\section{THE PURPOSE OF THERMAL CONDUCTIBILITY STUDY}

The purpose of study is to evaluate the conductibility of coronary vessels for the study of blood flow in the surface layer of the myocardium during warming up and cooling of the heart in conditions of cardiopulmonary bypass. The development of the method for contouring temperature inhomogeneities is associated with obtaining information on the state of the blood supply to the myocardium by separating the geometric boundaries between the cooled and warmed areas of the heart by using the algorithm of Canny's detecting and Gaussian filters for the video frames of the thermograms.

\section{METHODS AND MEASURES OF THE RESEARCH}

The temperature between the myocardium and the blood in the circuit of artificial blood circulation, which is cooled and warmed up in the heat exchanger, is measured using the thermograph FLIR ThermaCAM E300 having a temperature sensitivity of $0,1{ }^{\circ} \mathrm{C}$ and a measurement error of $\pm 1 \%$ of the range of measurements. The technical capabilities of the thermograph allow to determine the minimum difference in temperature between the heart and blood in the circuit of cardiopulmonary bypass from $0,5^{\circ} \mathrm{C}$ to $10^{\circ} \mathrm{C}$.

The contouring method for determining the conductibility of coronary vessels is realized on the basis of the contours algorithm of Canny detector that allows to distinguish the contours of the boundaries between different sections of the thermograms and divide them [9]. According to the algorithm, the selection of Canny detector is modified to study temperature gradients on the surface of the myocardium for analysis the stream of video data in the form of frames of thermograms that is recorded by the thermal imager and stored in the database of thermography images.

Clinical researches and researches on the basis of the method of mathematical modeling were conducted for estimation of efficiency of work of the algorithm of allocation of contours on the images of open heart.

\section{RESEARCH OF TEMPERATURE GRADIENTS ON THE HEART SURFACE}

For determine temperature gradients in conditions of cardiopulmonary bypass, it is necessary to control the temperature difference between coronary vessels and myocardium. The temperature difference at a distance from the vessel wall can be found from the equation for the amount of heat $Q_{m}$ that is transmitted to the myocardium through the surface of the vessel over an area of time $\tau$ [10-13]:

$$
Q_{m}=q \cdot S \cdot \tau=\frac{\lambda}{\delta}\left(T_{c}-T_{m}\right) \cdot S_{c} \cdot \tau
$$


where $q$ - the density of the heat flow through the surface of the vessel, $\mathrm{W} / \mathrm{m}^{2}$, $S_{c}$ - the surface area of the vessel, $m^{2}, \delta-$ the distance from the vessel wall, $m, T_{c}$ - blood temperature in the vessel, ${ }^{\circ} C, T_{m}$ - the temperature of the tissue of myocardium, ${ }^{\circ} \mathrm{C}$.

From the equation we find the temperature difference between the vessel and the myocardium:

$$
\Delta T=T_{c}-T_{m}=\frac{\delta}{\lambda} q .
$$

The ratio $\delta / \lambda$ characterizes the thermal conductibility of the myocardium, and the value determines the full temperature pressure from the vessels to the myocardium. For the current temperature of the blood $\Delta T_{i}$, that cools or warms up to a temperature $T_{i}$, it is possible to write the expression:

$$
\Delta T_{i}=T_{i}-T_{m}=\Delta T-\frac{\Delta T}{\delta} l,
$$

where $l-$ the distance from the vessel wall, through which the heat travels from the vessel to the depth of the myocardium, $m$.

The ratio $\Delta T / \Delta T_{i}$ is a dimensionless excess temperature that characterizes the temperature distribution from the vessel wall to the blood in the tissue of myocardium:

$$
\theta=\frac{\Delta T}{\Delta T_{i}}=1-\frac{l}{\delta}
$$

This expression is a temperature field equation in the assumption that the coefficient of thermal conductibility for the myocardium is a constant value. For determine the conditions for blood supply to the heart in small coronary vessels, it is advisable to estimate the change in the value $S_{i} / S_{m}$, which is the ratio of the warmed area of the myocardium to the total surface area $S_{m}$ at the same time intervals $\Delta t$ during hyperthermia:

$$
\theta=\frac{\Delta T}{\Delta T_{i}}=1-\frac{S_{i}}{S_{m}}
$$

where $S_{m}$ - total area of the surface of the myocardium, $m^{2}, S_{i}$ - surface area of the myocardium, through which the process of heat transfer occurs, $\mathrm{m}^{2}$.

With the thickness of the atrial walls $2-3 \mathrm{~mm}$ and the thickness of the walls of the left ventricle of the heart1 $1-14 \mathrm{~mm}$, which has the greatest thickness of the myocardium, the dependence of the coefficient of thermal conductibility on temperature $\lambda(T)$ has a virtually linear character $[25,26]$ :

$$
\lambda(T)=\lambda_{m}(1+b T),
$$


where $\lambda_{m}$ - the value of the coefficient of thermal conductibility of the myocardium for the temperature $T=0,0^{\circ} \mathrm{C}$ at the cooling of the heart, $W /(m \cdot K)$, $b$ - the empirical coefficient of the temperature curve.

For the arithmetic mean temperature at the area of myocardium - coronary vessels, the expression for the coefficient of thermal conductivity has the form:

$$
\lambda(T)=\lambda_{m}\left[1+\frac{b}{2}\left(T_{c}-T_{m}\right)\right]=\lambda_{m}\left[1+\frac{b}{2} \Delta T\right] .
$$

In this case, the expression for the density of the heat flux $q$ on the surface of the myocardium is as follows:

$$
q=\frac{\lambda(T)}{\delta}\left(T_{c}-T_{m}\right)=\frac{\lambda_{m}}{\delta}\left(T_{c}-T_{m}\right)\left[1+\frac{b}{2}\left(T_{c}-T_{m}\right)\right] .
$$

From this equation we find that the temperature difference $\Delta T$ in the layer of the myocardium is a nonlinear function, even for linear dependence of the coefficient of thermal conductivity of the myocardium $\lambda(T)$ :

$$
\Delta T=\sqrt{\frac{1}{b^{2}}-\frac{2 \delta}{b} \frac{q}{\lambda_{m}}}-\frac{1}{b} .
$$

If the heat flow from the vessels is transmitted to the myocardium due to heat transfer from the blood in the vessels, the specific heat flux is determined from the Newton-Richman equation [10]:

$$
q=\frac{\lambda_{C}(T)}{\delta}\left(T_{c}-T_{m}\right)=\alpha_{c}\left(T_{i}-T_{m}\right),
$$

where $\alpha_{c}$ - the value of the coefficient of heat transfer in the blood vessels.

Substituting the value of the heat flux in the expression for the temperature field, we obtain the dependence for the relation $S_{i} / S_{m}$ :

$$
\frac{S_{i}}{S_{m}}=1-\frac{\Delta T}{\Delta T_{i}}=1+\frac{1}{b \Delta T_{i}}-\sqrt{\left(\frac{1}{b \Delta T_{i}}\right)^{2}-\frac{2 \delta}{b} \frac{\alpha_{c}}{\lambda_{m} \Delta T_{i}}} .
$$

Thus, the resulting dimensionless value $F=S_{i} / S_{m}$ is determined by the rate of change in blood temperature in the vessels - the thermal conductibility of the blood $\lambda_{C}$, the thermal conductibility of the myocardium $\lambda_{m}$, the difference in temperature between the blood and the myocardium $\Delta T_{i}$, as well as the sign and numerical values of the coefficient $b$ for the temperature curve. The deviation of the values of the ratio $F$ from the linear dependence for the temperature field equation $\theta$ characterizes the uneven distribution of the temperature in the myocardium owing to the different rate of heat propagation in the medium (Fig. 1): 


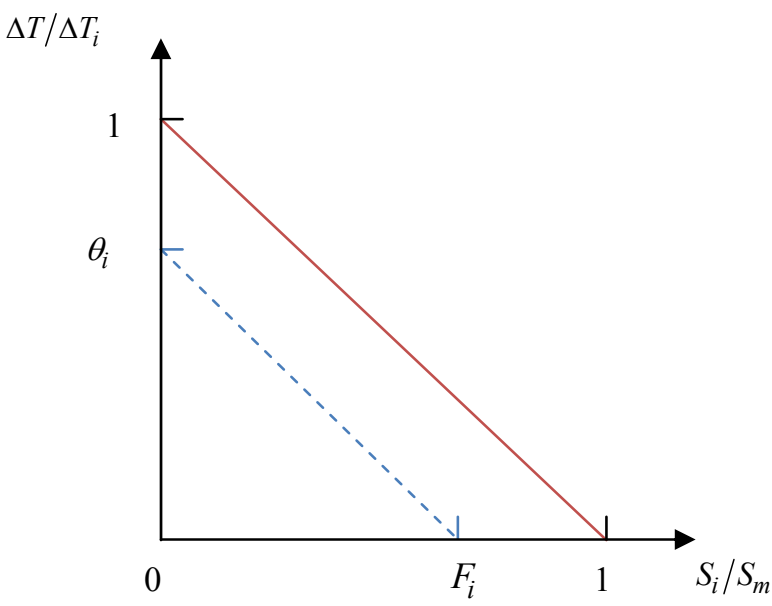

Fig. 1. Curves of temperature distribution in the layer of the myocardium for the temperature field equation

The relative deviation $\Delta_{F}$ from the linear dependence in the temperature field equation for the current temperature flux is calculated as the difference between the areas under the temperature distribution curves:

$$
\Delta_{F}=\left(1-F_{i} \cdot \theta_{i}\right)<1 \text {. }
$$

where $\theta_{i}$ - the current value of the ratio $\Delta T / \Delta T_{i}, F_{i}$ - the current value of the ratio $S_{i} / S_{m}$.

Obviously, in other equal conditions, the temperature in the myocardium $\Delta T_{i}$ varies so rapidly, the greater the density of the heat flux through the surface $S_{i}$, therefore, the current value of the ratio $F=S_{i} / S_{m}$ should approach the value $F_{i} \rightarrow 1$.

\section{CONTOURING METHOD FOR DETERMINING CONDUCTIBILITYOF CORONARY VESSELS}

In accordance with the contouring method of temperature inhomogeneities for the selection of Canny contours, modified to study the gradients of temperature on the surface of the myocardium, the stream of video data in the form of thermogram frames is recorded by the thermal imager and stored in the thermographic image database.

The first stage of treating the thermograms of the heart is the selection on the thermograms of temperature profiles, converted at the signal level. This procedure is carried out by applying threshold filtering. Since the level of thermal interference makes an error in determining the levels of temperature profiles that leads to distortion of the useful signal the interface of the Canny detector $[14,15]$ is used. The Canny boundary detector is a one-dimensional operator, which provides an optimal match between localization of thermal inhomogeneity and contour allocation. As criteria of optimality use to such criteria as probability of detec- 
tion, high accuracy of localization, unambiguous response to one selection contours. The operator Canny maximizes the sum of two criterias: the probability of passage or false detection of the boundary, and the determination of the distance between the true and the isolated edges of the thermal heterogeneity. The first criterion leads to a reduction in the likelihood of the re-identification of the same edge heterogeneity. The second criterion allows you to determine the contrast margin and outline lines for the boundaries in the image using a certain threshold value, which use to compares the length of the gradient vector.

The algorithm for the operation for the circuit of Canny detector includes the following steps (Fig. 2):

1. Thermography image frames $I(x, y)$ are divided into segments for which the processing and detection of contours within each segment are performed:

$$
I(x, y)=\sum_{k=1}^{N} I_{k}(\Delta x, \Delta y),
$$

where $N$ - the number of segments of the representation of the image, $I(x, y)$ - the intensity of the pixels of the thermographic image, $I_{k}(\Delta x, \Delta y)-$ the segmentation of the image along the coordinates $x$ and $y$.

2. The low frequency Gaussian Filtering. The each image segment is smoothed with use to Gaussian convolution:

$$
G(x, y, \sigma)=\frac{1}{2 \pi \sigma^{2}} \exp \left(\frac{x^{2}+y^{2}}{2 \sigma^{2}}\right),
$$

where $\sigma$ - the degree of smoothing parameter.

3. Calculation of the gradient of the intensity of the pixels of the image in the vertical (axis $x$ ) $g(x)$ and horizontal (axis $y) g(y)$ directions with the help of the operators of the first derivative. Definition of the gradient module:

$$
E_{k}(x, y)=\sqrt{g(x)^{2}+g(y)^{2}} .
$$

3. Clarification of the contours found in the previous step is accomplished by resetting the gradient values $E_{k}(x, y)$ for those elements of the image that are not actually in the maximum of the gradient. The analysis starts from the point of maximum, that has a gradient value more than $T_{1}$ and lasts as long as the local maximum value does not become less than the threshold $T_{2}<T_{1}$ :

$$
E_{k}(x, y)=\left\{\begin{array}{c}
E_{k}(x, y), \quad T \geq T_{1}, \\
0, \quad T \in\left(-\infty, T_{1}\right) .
\end{array}\right.
$$

4. The resulting image is subjected to threshold processing using two temperature thresholds $T_{1}$ and $T_{2}$, moreover $T_{1}>T_{2}$. Pixels of an image having an intensity value greater then, are defined as strong $p_{k}^{+}(x, y)$, and pixels whose values fall into an interval $\left[T_{1}, T_{2}\right]$ are defined as weak $p_{k}^{-}(x, y)$ pixels: 


$$
p_{k}(x, y)= \begin{cases}p_{k}^{+}(x, y), & T \in\left(T_{2}, \infty\right), \\ p_{k}^{-}(x, y), & T \in\left[T_{1}, T_{2}\right] .\end{cases}
$$

5. Selecting the maximum response. For each image frame, the maximum response is determined as the value of the gradient module, which determines the affinity of the temperature profile to the given segment of the thermography image:

$$
E(x, y)=\max _{k \rightarrow N}\left|E_{k}(x, y)\right| .
$$

The algorithm for forming the contour ends with a morphological operation, in which the weak pixels are added to the strong pixels. Smoothing values of pixel intensity $I_{k}(x, y)$ increases the resistance of the Canny detector:

$$
I_{k}(x, y)= \begin{cases}p_{k}^{+}(x, y)+p_{k}^{-}(x, y), & T \in\left(T_{2}, \infty\right), \\ p_{k}^{-}(x, y), & T \in\left[T_{1}, T_{2}\right], \\ 0, & T \in\left(-\infty, T_{1}\right) .\end{cases}
$$

According to the algorithm of the work of the Canny's limit detector, pixels of images are assigned to pixels of the boundary, which give the local maximum of the gradient in the direction of the temperature change vector. As a result, pixels marked white will be considered as a potential limit, all others will be excluded and marked with black. Pixels located in the immediate proximity to one of the vertical and horizontal directions are defined as the resulting contour of the boundary, and pixels lying alone or away from the boundary are removed.

In order to evaluate the efficiency of the algorithm for selecting the contours for open heart images in the presence of an additive obstacle, research was carried out using the mathematical modeling method. For this purpose, the model images of the area of the myocardium, containing an additive obstruction in the form of normal "white noise" with a given peak signal to noise ratio, were synthesized. The received noisy images were digitally processed according to the developed algorithm circuit of the Canny's detector at various values of the detector parameters, including the parameter $\sigma$ characterizing the Gaussian linear filter, the values of the temperature thresholds $T_{1}$ and $T_{2}$ that determining the conditions for the segmentation of the images.

From the results of the numerical experiment it is clear that the procedure for determining the binary areas provides for the exclusion of false contours only when carefully selecting the parameter $\sigma$ for filtering the original image. Therefore, the value of this parameter, which specifies the degree of image smoothing to filter interference, was selected experimentally and consisted of values: 


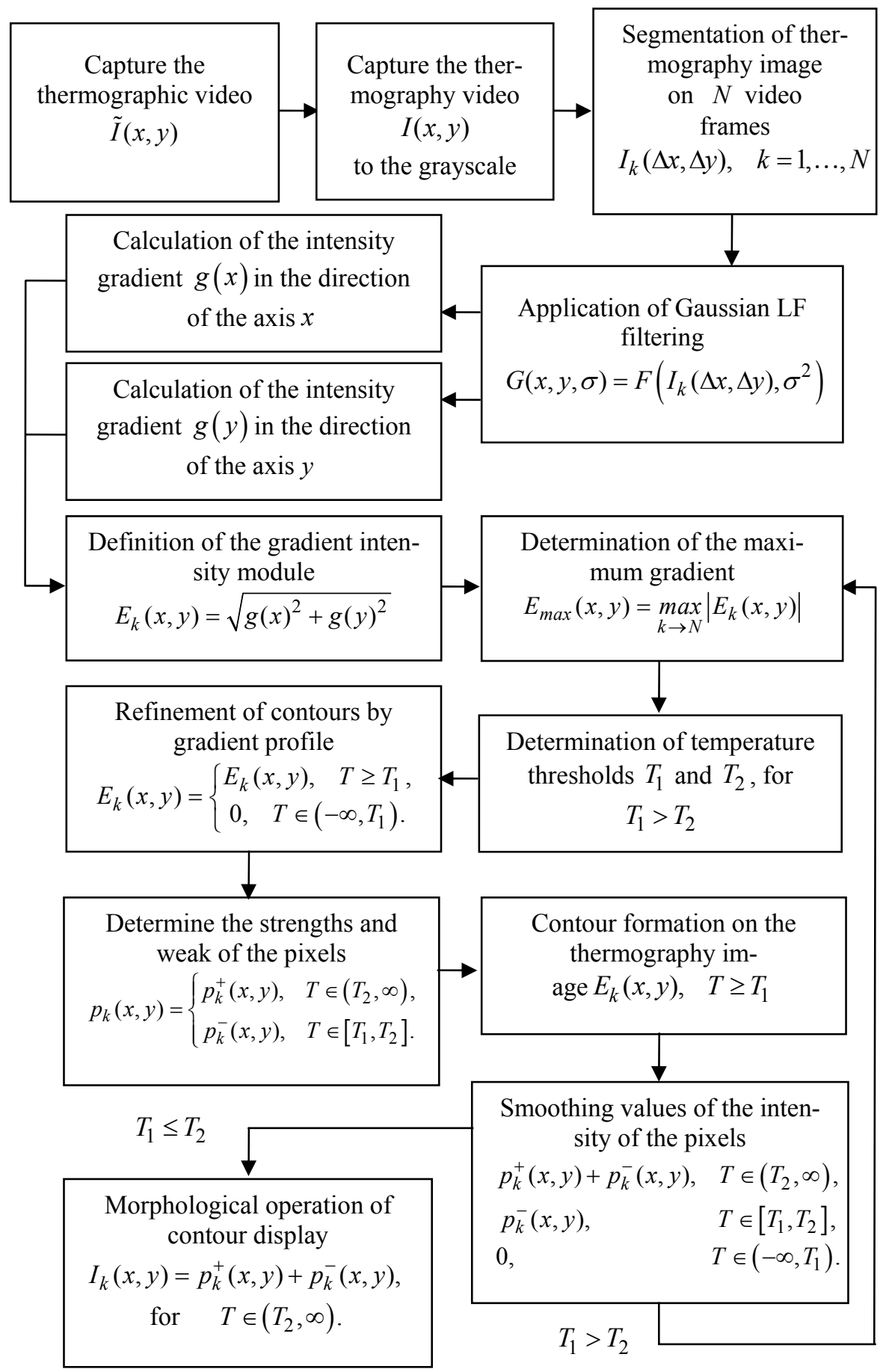

Fig. 2. Algorithm of the Canny's detector using the Gaussian filter, threshold filtering and smoothing values of the intensity of the pixels 


$$
\begin{gathered}
\sigma=1,4 \text { for threshold }\left[T_{1}, T_{2}\right]=\left[14^{0} C, 18^{0} C\right] \text { with hypothermia, } \\
\sigma=2,0 \text { for threshold }\left[T_{1}, T_{2}\right]=\left[32{ }^{0} C, 36{ }^{0} C\right] \text { with hyperthermia. }
\end{gathered}
$$

Thus, the Canny's limit detector determines how fast the brightness of the image changes at each point of the thermograms, which makes it possible to determine the boundaries of temperature heterogeneity and its orientation.

\section{CLINICAL STUDIES}

The clinical investigations of the method for conduction of coronary vessels were carried out at the clinical base of the Amosov National Institute of Cardiovascular Surgeryof NAMS of Ukraine to improve the efficiency of noninvasive control of human heart temperature in conditions of artificial blood circulation in the department of surgical treatment of aortic pathologies in sixteen open heart operations and in the department of surgical treatment of acquired heart defects in twelve open heart operations.

In clinical studies, the process of warming up and cooling myocardium is carried out through the cannulas, which are installed in the anterior part of the aorta in the region of the top of the heart. The cannula is installed in the branch of the right ventricular artery for pumping a cardioplegic solution along the right coronary artery, and the cannula is installed on the surface of the aortic bulb for pumping the solution along the left coronary artery.

The clinical studies on isolated heart show the feasibility of using the method of determining the conductibility of coronary vessels on the basis of noninvasive heart temperature control for assessing the conditions of blood supply to the vessels of the myocardium (Fig. 3).

When cooling the heart (Fig. 3 a), the coronary vessels are clearly distinguished at the temperature difference between the tissues of the myocardium and the solution $6^{\circ} \mathrm{C}$ and more (to a temperature of $10^{\circ} \mathrm{C}$ ). Accordingly, when warming the heart (Fig. $3 \mathrm{~b}$ ), the coronary vessels are released at a temperature difference of $9^{\circ} \mathrm{C}$ or more (up to $12^{\circ} \mathrm{C}$ ). The initial temperature of the myocardium at the beginning of the cooling process was not less than $21-22^{\circ} \mathrm{C}$, and at the beginning of the warming - no more than $25-26^{\circ} \mathrm{C}$.

The assessment of the dynamics of temperature changes for the distribution of temperature in the myocardium can be performed for a sequence of thermograms of the heart that are performed for the state of hypothermia and hyperthermia in conditions of cardiopulmonary bypass (Fig. 4).

The application of the developed mathematical model of heat exchange for the surface layer of the myocardium [16 - 18] allows us to determine the boundaries between the warmed and cooled sections of the myocardium during hypothermia or hyperthermia of the heart. When cooling the heart (Fig. 4a) and warming the heart (Fig. 4b), the boundaries between the warmed and cooled areas are allocated due to the presence of a gradient on the surface of the myocardium at temperatures between $0.5^{\circ} \mathrm{C}$ and $4^{\circ} \mathrm{C}$ and more. 


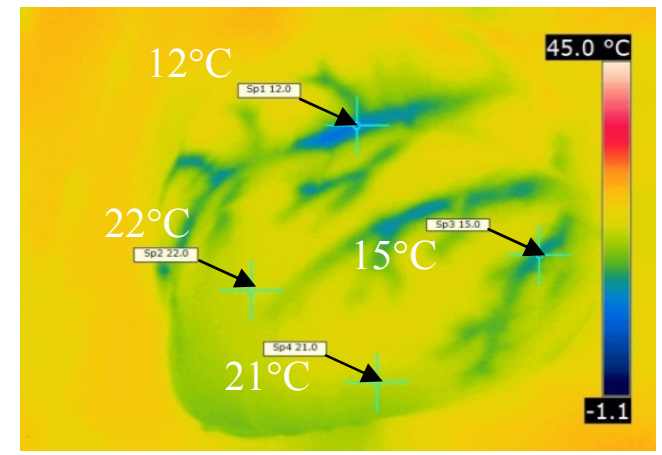

a

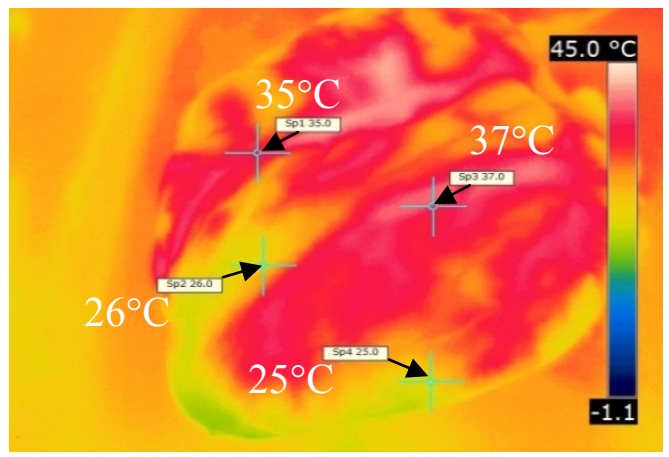

$\mathrm{b}$

Fig. 3. Application of the thermographic method of contouring to determine the conductivity of coronary vessels: a - for cooled heart; $b$ - for a warmed heart

During hypothermia (Fig. 5), the area of the warm part of the myocardium decreases by compressing the cooling circuit $S_{\text {gipo }}$ and, accordingly, increasing the area of the cooled area relative to the external cooling circuit limit $S_{o}$. The dynamics of temperature changes on the surface of the heart causes an increase in the magnitude of the ratio $S_{i} / S_{m}$ and brings it closer to the value $F_{i} \rightarrow 1$.

During hyperthermia (Fig. 6) there is a decrease in the area of the chilled area of the myocardium by compressing the warming contour $S_{\text {giper }}$ and, accordingly, increasing the area of the warmed area relative to the external warming circuit limit $S_{\text {gipo. }}$. The dynamics of temperature changes on the surface of the heart causes an increase in the magnitude of the ratio $S_{o}$ and brings it closer to the value $F_{i} \rightarrow 1$.

At the final stage of the processes of hypothermia and hyperthermia, the value $F_{\text {gipo }}=S_{\text {gipo }} / S_{o}$ is less than 1.3 times the value $F_{\text {giper }}=S_{\text {giper }} / S_{o}$, respectively, which is expressed in a more uniform warming of the studied area of the heart with hyperthermia in comparison with the process of its cooling under hypothermia in conditions of cardiopulmonary bypass. 


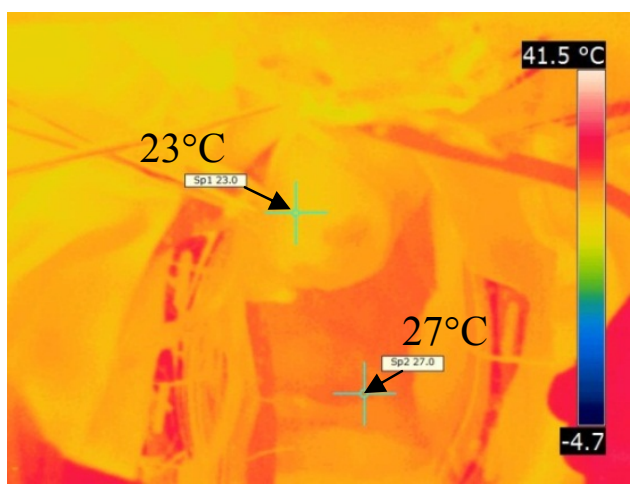

a

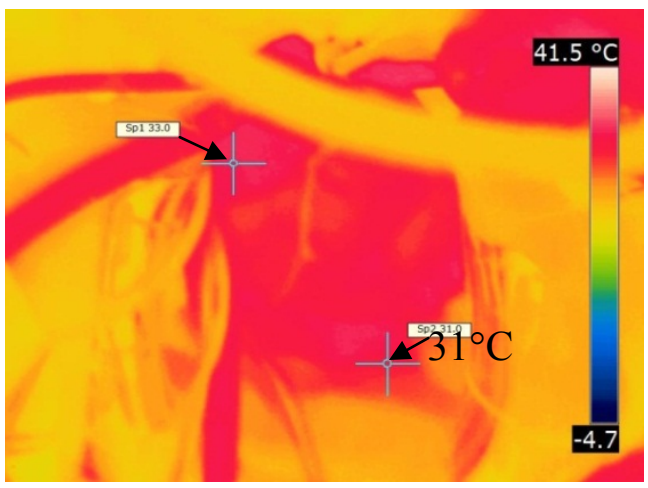

b

Fig. 4. Thermograms of the heart for the state of hypothermia and hyperthermia: a — for a cooled heart; $b$ - for a warmed heart

The developed method for determining the conductibility of coronary vessels provides the reliability of non-invasive control of open heart temperature, which is determined by the temperature sensitivity of $0,1^{\circ} \mathrm{C}$ of the thermometer FLIR ThermaCAM E300 and the measurement error $\pm 1 \%$ of the range.In addition, the use of needle heaters and sensors in the oesophagus does not allow to determine the temperature of the inner wall of the myocardium without the introduction of invasive sensors in the opening between the aorta and the left ventricle, which is an additional factor for injury. 


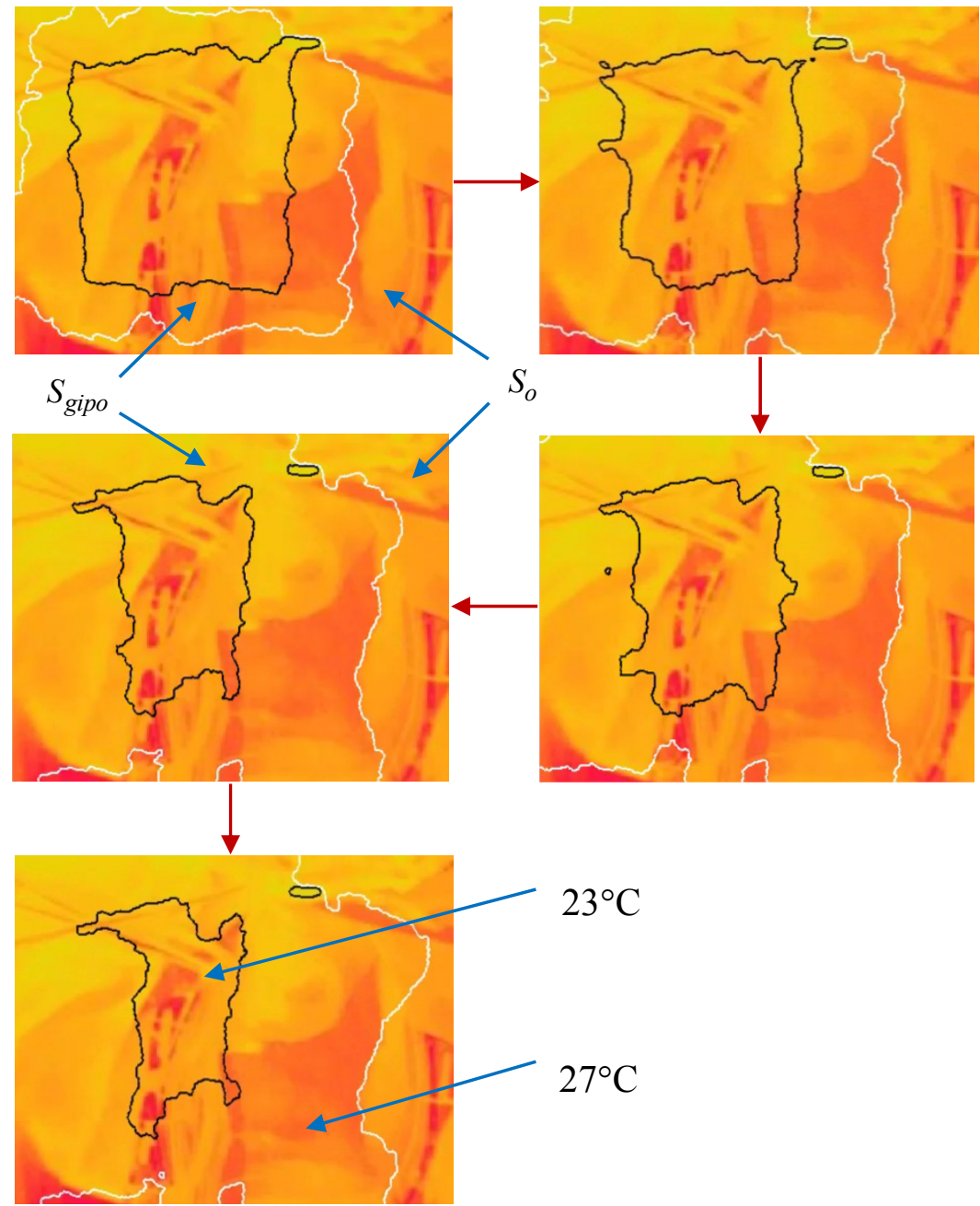

Fig. 5. Work of the Canny detector algorithm for hypothermia of the heart 


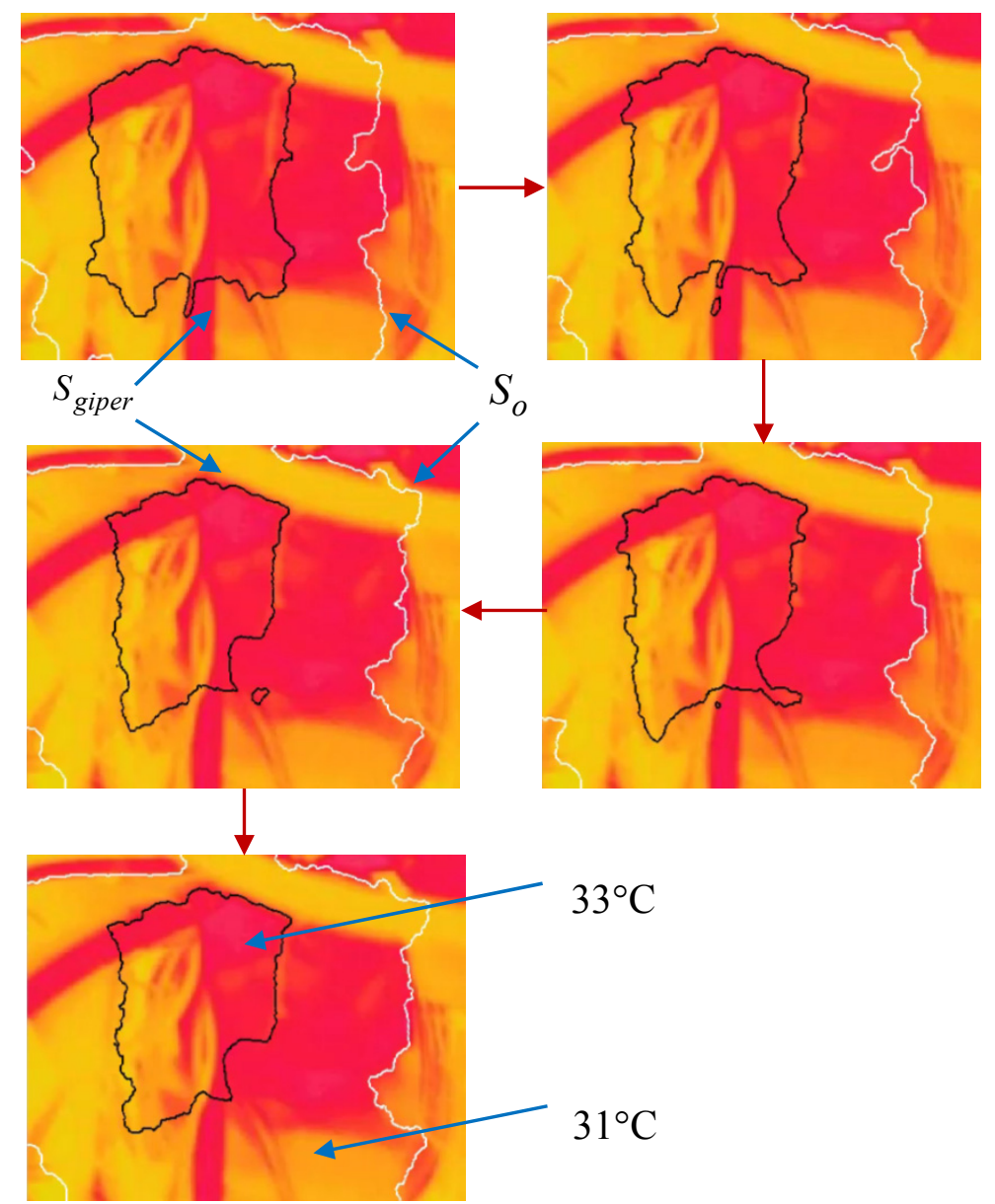

Fig. 6. Work of the Canny detector algorithm for hyperthermia of the heart

\section{RESULTS}

For compare the temperature data, that is measured using invasive needle sensors and the thermography method, the determination of regression dependence for the calculation of the dynamic changes in temperature, determined in real time. As a data examination class $\left(C_{1}\right)$, the temperature value measured with the needle sensors $\triangle T_{M E D}(t)$ is used. The investigated class $\left(C_{2}\right)$ contains calculated temperature differences on the surface of the myocardium $\Delta T_{F L I R}(t)$, which are recorded during hypothermia and hyperthermia using the thermography.

The level of confidence in the obtained temperature data, measured by thermography means and needle sensors, reflects the value of confidence intervals. The obtained confidence intervals can be considered as an interval of values of the parameters, which does not contradict the true value of temperature. In determining the Euclidean distance by the $K$-mean method, the number of observations corresponding to the number of temperature measurements $k=10$ is taken into account. The calculated Euclidean distance between the center of 
gravity of the examination class $\left(C_{1}\right)$ and the studies class $\left(C_{2}\right)$ is researched that equals $d\left(c_{1}, c_{2}\right)=6,69$. The resulting value of the confidence interval is less than $15 \%$ shows the closeness between the data in the classes.

The reliability of determining the coefficient of correlation $r\left(c_{1}, c_{2}\right)$ depends on the number of measurements of temperature and the number of degrees of freedom $k=n-2$. The value of the t-criterion for assessing the statistical significance of the correlation relationship between the samples is determined by the formula:

$$
t(r)=\frac{\sqrt{r\left(c_{1}, c_{2}\right)^{2}}}{\sqrt{1-r\left(c_{1}, c_{2}\right)^{2}}} \sqrt{n-k},
$$

where $n$ - the number of temperature measurements, $k$ - the number of degrees of freedom for pair regression.

The results of the regression analysis of the temperature measurement data are to determine the correlation coefficient $r\left(c_{1}, c_{2}\right)=0,739$ and the regression equation on the basis of comparison of data $x_{i}, y_{i}$ in the classes $C_{1}$ and $C_{2}$ to the studies (Table 1).

The critical value of Student's t-criterion is located $t_{\text {crit }}=2,306$ for the sample $n=10$ size and the number of degrees of freedom $k=2$ at the level of significance $p<0,05$. The calculated t-criterion $t(r)=3,102$ for a specific correlation coefficient $r\left(c_{1}, c_{2}\right)$ is greater than the critical value $t(r)>t_{c r i t}$, hence the relationship between data in classes $C_{1}$ and $C_{2}$, is statistically significant. The resulting regression equation $y=0,3829 x+0,2137$ (Fig. 7) has a large angle of inclination of the data interrelation 0,3829 and linear dependence, and allows you to perform the conversion of temperature readings, measured with the help of needle sensors, to the temperature values obtained using the thermography method.

Table 1. Results of regression analysis of temperature control data for the method of determining the conductibility of coronary vessels

\begin{tabular}{|l|c|c|}
\hline \multicolumn{2}{|c|}{ Evaluation criterion } & $\begin{array}{c}\text { The value of the coeffi- } \\
\text { cient }\end{array}$ \\
\hline - Correlation coefficient & $r\left(c_{1}, c_{2}\right)$ & 0,739 \\
\hline - t-criterion value & $t(r)$ & 3,102 \\
\hline - Regression equation & $y=0,3829 x+0,2137$ & 0,383 \\
\hline
\end{tabular}




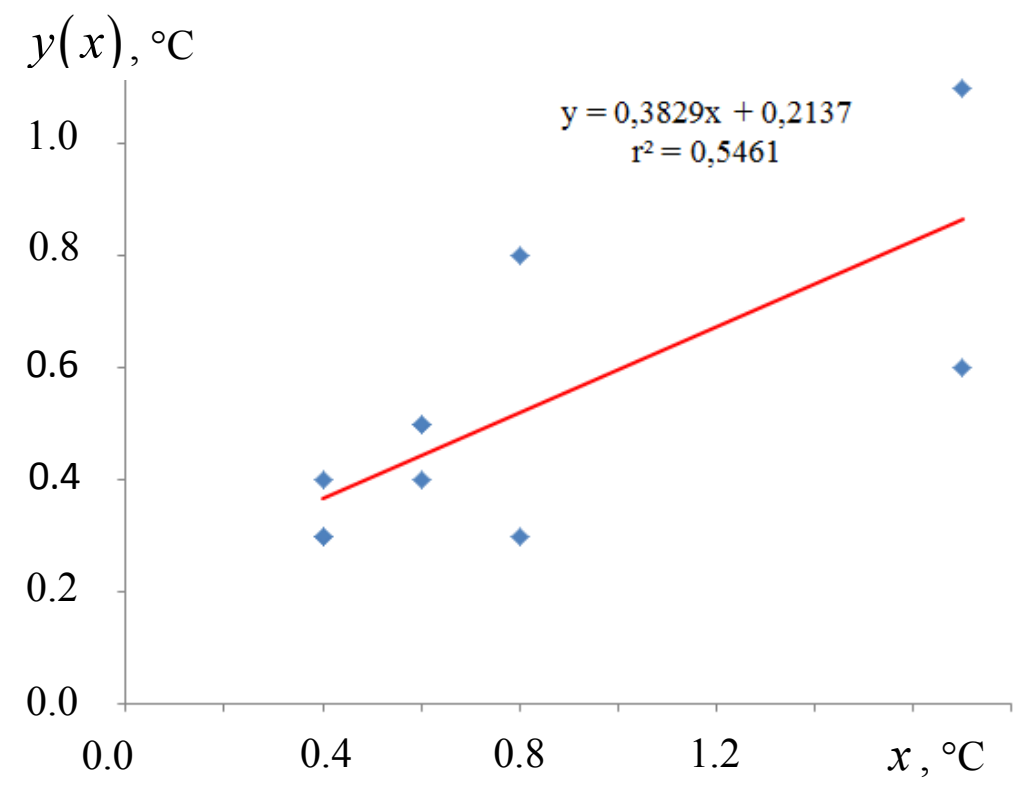

Fig. 7. Regression equation based on the comparison of data $x_{i}, y_{i}$ in classes: $x$ - data of the examination class $C_{1}$ of heat sensor, $\Delta T_{M E D}(t),{ }^{\circ} \mathrm{C}, y$ - class data $C_{2}$ for thermographic studies, $\left.\Delta T_{F L I R} t\right),{ }^{\circ} \mathrm{C}$.

The proposed algorithm for obtaining contours of areas with nonhomogeneous temperature distribution on the surface of the heart, realized on the basis of the contours algorithm of Canny detector, allows receiving additional information on the state of the blood supply of the myocardium by using the Gaussian filter, and on the basis of the informative temperature profiles on thermographic images, separating the geometric boundaries between the cooled and warmed up areas of the myocardium by using the algorithm of Canny detecting for the video frames of thermograms.

The obtained regression dependences have the correlation coefficient of 0.75 , that allows to perform the conversion of heart temperature readings, which are measured with the help of needle heaters in the temperature values, obtained using the thermography method. The reliability of the method for determining the conductibility of coronary vessels for the detection of myocardial areas with the ischemic regions with dimensions less than $2 \times 2 \mathrm{~mm}$ can be increased by using modern medical thermographs with a sensitivity of $0,02^{\circ} \mathrm{C}$ and a measurement error of $\pm 0,5 \%$ of the range.

Thus, the use of the thermography method for determining the conductibility of coronary vessels in comparison with the use of needle heaters for the evaluation of microhemodynamics of coronary vessels can significantly increase the reliability of heart temperature control due to the possibility of obtaining additional information for the permissible difference in temperature on the surface of the myocardium during hypothermia and hyperthermia. 


\section{CONCLUSIONS}

Thus, the method of contouring the cooled and warmed areas of the myocardium to determine the conductibility of coronary vessels using thermographic instruments for measuring the temperature of the heart, and an improved of the algorithm of detector Canny using the Gaussian filter, allows us to assess the conductibility of coronary vessels for the study of blood flow in the surface layer of the myocardium during warming up and cooling of the heart in conditions of cardiopulmonary bypass.

The application of the thermography method for determining the conductibility of coronary vessels in comparison with the use of needle heaters for the evaluation of microhemodynamics of coronary vessels provides non-invasive control of heart temperature and the possibility of obtaining additional information on the permissible difference in temperature on the surface of the myocardium during hypothermia and hyperthermia.

\section{REFERENCES}

1. Nicholas A., Diakides B., Joseph D., Bronzino A. Medical Infrared imaging. RC Press Taylor Group LLC, London. 2008. 451p.

2. Kotovskyi V., Shlykov V., Vi?niakovc N., And?ela?e?ok. The IR-thermal imaging method for evaluation of the status of myocardial coronary vessels under the condition of artificial blood circulation. Technology and Health Care. vol. Pre-press, no. Pre-press. 2018. P. 1-6.

3. Maksymenko V., Danilova V., Shlykov V. The discrete model for the system of the myocardium and coronary vessels. 3rd Conference "Approximation Methods for Molecular Modelling and Diagnosis Tools" (26-30 $0^{\text {th }}$ of Jan., 2017, Kyiv). Kyiv, 2017. P. 3. (in Ukranian)

4. Shlykov V., Danilova V., Maksymenko V. Heat transfer model based on thermographic imaging of the heart in open chest conditions. 17th European Congress on Extracorporeal Circulation Technology. (14-17 $7^{\text {th }}$ of June, 2017, Marseille). Marseille, 2017. P. 57.

5. Maksymenko V., Danilova V., Shlykov V. The Discrete Model for the System of the Myocardium and Coronary Vessels. Scientific news of NTUU "KPI". No 1 (2017). P. 54-60. (in Ukranian)

6. Shlykov V., Danilova V., Maksymenko V. The Model of the Myocardium in the MSC Sinda System. Cardiology and Cardiovascular Research Vol 1 Issue 2. 2017. P. 18-22.

7. Shlykov V., Danilova V., Maksymenko V. Numerical model for heat transfer based on thermographic imaging of the heart. Standardization, Certification, Quality №4(107). 2017. P. 62-68. (in Ukranian)

8. Shlykov V., Danilova V., Maksymenko V., Sychyk M. Application of Model of Heat Exchange for Myocardium Provided Stationary Convection Laminar Flow. Journal of Cardiology \& Current Research. 2017. P. 311-313.

9. Chen J. S., Huertas A., Medioni G. Fast convolution with Laplacian-of-Gaussian masks. IEEE Transactions of Pattern Analysis and Machine Intelligence. 1987. Vol. 9, Issue 4. P. 584-590. doi: 10.1109/tpami.1987.4767946

10. John H. Lienhard IV, John H. Lienhard V. A Heat Transfer Textbook 4th ed. Cambridge, MA: Phlogiston Press. 2017. 768 P.

11. MSC Sinda 2017 User's Guide. Docs ID DOC11364. MSC Software Corporation. 2017. 451 P.

12. Kelly T. Thermal Analysis Kit III Manual. K\&K Associates, Version 97.003. 1997. 23 p..

13. Thermal Network Modeling Handbook. K\&K Associates, Developers of Thermal Analysis Kit, Version 97.003. 2000. 29 p.

14. Sharif, M., Mohsin S. Single Image Face Recognition Using Laplacian of Gaussian and Discrete Cosine Transforms. The International Arab Journal of Information Texnology. 2012. Vol. 9, Issue 6. P. 562-570.

15. Canny J. A computational approach to edge detection. IEEE Transactions on pattern analysis and machine intelligence. 1986. Vol. 8, Issue 6. P. 679-698. doi: 10.1109/tpami.1986.4767851 
16. Khudetskyy I.U., Danilova V.A., Shlykov V.V. Use of Thermal Imaging for Control of the Process Hypothermia Cardiac. The Polish Journal of Applied Science. 2015. P. 93-96

17. Kotovskiy, V. I., Shlykov, V. V., Danilova, V. A. The Method of Processing Thermographic Images for the Open Heart. Young Scientist USA. Vol. 7. 2017. P. 1.3-3.3

18. Shlykov V. The propagation of the temperature wave in myocardium. "EUREKA: Physics and Engineering». №2 (2018) P. 52-62.

19. Bin Jing, Haiyun Li. A Novel Thermal Measurement for Heart Rate. Journal of Computers Vol. 8, No. 9, Academy Publisher, 2013. P. 2163-2166 URL: https://pdfs.semanticscholar.org/6c24/5901e748c240f7f82ff42d726db2573c3262.pdf (Last accessed: 01.06.2019).

20. Buckberg G.D., Brazier J.R., Nelson R.L., et al. Studies of the effects of hypothermia on regional myocardial blood flow and metabolism during cardiopulmonary bypass. I. The adequately perfused beating, fibrillating, and arrested heart. $J$ ThoracCardiovascSurg 1977; 73: 87-94.

21. Love T. J. Thermography as an indicator of blood perfusion. Annals of the New York Academy of Sciences. 1980.V. 335. № 1. P. 429-437.

22. Gonzalez R.C., Woods R.E. Digital Image Processing Prentice Hall, 2002. URL: http://users.dcc.uchile.cl/ jsaavedr/libros/dip_gw.pdf

23. Stoica P., Moses R. Spectral analysis of signals. Prentice Hall, New Jersey, 2004. URL: http://user.it.uu.se/ ps/SAS-new.pdf (Last accessed: 01.06.2019)

24. Pavlidis T. Algorithms and Graphics and Image Processing. N.Y.: Springer, 1982. 320 p.

25. Chepurny M. M., Resident N.V. Heat exchange in examples and tasks: a manual / Vinnitsa: VNTU, 2011. 128 p. (in Ukranian)

26. Gilchuk A.V., Khalatov A.A. Theory of Thermal Conductivity: Textbook. Kyiv: Igor Sikorsky Kyiv Polytechnic Institute, 2017.93p. (in Ukranian)

Received 29.03.2019

\section{ЛИТЕРАТУРА}

1. Nicholas A., Diakides B., Joseph D., Bronzino A. Medical Infrared imaging RC Press Taylor Group LLC, London. 2008. 451p.

2. Kotovskyi V.,Shlykov V., Vi?niakove N., And?ela?e?ok. The IR-thermal imaging method for evaluation of the status of myocardial coronary vessels under the condition of artificial blood circulation. Technology and Health Care. vol. Pre-press, no. Pre-press. 2018. P. 1-6.

3. Maksymenko V., Danilova V., Shlykov V. The discrete model for the system of the myocardium and coronary vessels. 3rd Conference "Approximation Methods for Molecular Modelling and Diagnosis Tools" (26-30 ${ }^{\text {th }}$ of Jan., 2017, Kyiv). Kyiv, 2017. P. 3. (in Ukranian)

4. Shlykov V., Danilova V., Maksymenko V. Heat transfer model based on thermographic imaging of the heart in open chest conditions. 17th European Congress on Extracorporeal Circulation Technology. (14-17 $7^{\text {th }}$ of June, 2017, Marseille). Marseille, 2017. P. 57.

5. Maksymenko V., Danilova V., Shlykov V. The Discrete Model for the System of the Myocardium and Coronary Vessels. Наукові вісті НТУУ "КПI". No 1 (2017). C 54 60. (in Ukranian)

6. Shlykov V., Danilova V., Maksymenko V. The Model of the Myocardium in the MSC Sinda System. Cardiology and Cardiovascular Research. Vol. 1, Issue 2. 2017. P. 18-22.

7. Shlykov V., Danilova V., Maksymenko V. Numerical model for heat transfer based on thermographic imaging of the heart. Стандартизація, сертифікація, якість. Вип. №4(107) 2017. C 62 - 68. (in Ukranian)

8. Shlykov V., Danilova V., Maksymenko V., Sychyk M. Application of Model of Heat Exchange for Myocardium Provided Stationary Convection Laminar Flow Journal of Cardiology \& Current Research. 2017. P. 311-313.

9. Chen J. S., Huertas A., Medioni G. Fast convolution with Laplacian-of-Gaussian masks IEEE Transactions of Pattern Analysis and Machine Intelligence. 1987. Vol. 9, Issue 4. P. 584-590. doi: 10.1109/tpami.1987.4767946

10. John H. Lienhard IV and John H. Lienhard V A Heat Transfer Textbook - 4th ed. Cambridge, MA: Phlogiston Press. 2017. 768 P. 
11. MSC Sinda 2017 User's Guide. Docs ID DOC11364 MSC Software Corporation. 2017. 451 P.

12. Kelly T. Thermal Analysis Kit III Manual. K\&K Associates, Version 97.003. 1997. 23 P.

13. Thermal Network Modeling Handbook. K\&K Associates, Developers of Thermal Analysis Kit, Version 97.003. 2000. 29 P.

14. Sharif, M., Mohsin S. Single Image Face Recognition Using Laplacian of Gaussian and Discrete Cosine Transforms. The International Arab Journal of Information Texnology. 2012. Vol. 9, Issue 6. P. 562-570.

15. Canny J. A computational approach to edge detection. IEEE Transactions on pattern analysis and machine intelligence. 1986. Vol. 8, Issue 6. P. 679-698. doi: 10.1109/tpami.1986.4767851

16. Khudetskyy I.U., Danilova V.A., Shlykov V.V. Use of Thermal Imaging for Control of the Process Hypothermia Cardiac. The Polish Journal of Applied Sciences. 2015. P. 93-96

17. Kotovskiy, V. I., Shlykov, V. V., Danilova, V. A. The Method of Processing Thermographic Images for the Open Heart. Young Scientist USA. Vol. 7. 2017. P. 1.3-3.3

18. Shlykov V. The propagation of the temperature wave in myocardium. "EUREKA: Physics and Engineering». №2 (2018) P. 52-62.

19. Bin Jing, Haiyun Li. A Novel Thermal Measurement for Heart Rate. Journal of Computers. Vol. 8, No. 9, September. Academy Publisher, 2013. pp. 2163-2166. URL: https://pdfs.semanticscholar.org/6c24/5901e748c240f7f82ff42d726db2573c3262.pdf (Last accessed: 01.06.2019).

20. Buckberg G.D., Brazier J.R., Nelson R.L., et al. Studies of the effects of hypothermia on regional myocardial blood flow and metabolism during cardiopulmonary bypass. I. The adequately perfused beating, fibrillating, and arrested heart. $J$ Thorac Cardiovasc Surg 1977; 73: 87-94.

21. Love T. J. Thermography as an indicator of blood perfusion. Annals of the New York Academy of Sciences. 1980.V. 335. № 1. P. 429-437.

22. Gonzalez R. C., Woods R.E. Digital Image Processing Prentice Hall, 2002. URL: http://users.dcc.uchile.cl/ jsaavedr/libros/dip_gw.pdf (Last accessed: 01.06.2019)

23. Stoica P., Moses R. Spectral analysis of signals. Prentice Hall, New Jersey, 2004. URL: http://user.it.uu.se/ ps/SAS-new.pdf (Last accessed: 01.06.2019)

24. Pavlidis T. Algorithms and Graphics and Image Processing. N.Y.: Springer, 1982. 320 P. 25.

25. Чепурний М.М., Резидент Н.В. Тепломасообмін в прикладах і задачах: навчальний посібник Вінниця: ВНТУ. 2011. 128 с. (in Ukranian)

26. Гільчук А.В., ХалатовА.А.Теорія теплопровідності: навчальний посібник Київ: КПІ ім. Ігоря Сікорського, 2017. 93c. (inUkranian)

Отримано 29.03.2019 
Шликов В.B. ${ }^{l}$, канд.техн.наук, доцент, доцент кафедри біомедичної інженерії

Київського політехнічного інституту ім. Ігоря Сікорського

e-mail: v.shlykov@kpi.ua

Максименко В.Б. ${ }^{2}$, д-р.мед.наук, професор,

Заст.директора $з$ наукової роботи

Київського політехнічного інституту ім. Ігоря Сікорського

e-mail: maksymenko.vitaliy@gmail.com

${ }^{1}$ Національний технічний університет України "Київський політехнічний інститут імені Ігоря Сікорського"

пр. Перемоги, 37, Київ, Україна, 03056

${ }^{2}$ Національний інститут серцево-судинної хірургії імені М.М. Амосова вул. Амосова, 6, Київ, Україна, 03038

МЕТОД ВИЗНАЧЕННЯ ПРОВІДНОСТІ КОРОНАРНИХ СУДИН ЗАСОБАМИ ТЕРМОГРАФІЇ

Вступ. Характер розподілу температури в серці визначається процесом теплообміну між міокардом і коронарними судинами, а також станом мікрогемодинаміки коронарного русла серця. Для кількісного оцінювання нерівномірності розподілу температури на поверхні серця запропоновано алгоритм розрахунку кількісного критерію, що може бути об'єктивним маркером ефективного захисту серця і мозку. Метод визначення провідності коронарних судин реалізовано на основі алгоритму визначення теплових контурів, що обчислюються за градієнтами температурного поля на зображенні серця в інфрачервоному спектрі. Вдосконалення розробленого раніше методу визначення теплових контурів на основі алгоритму Канні полягає в переході від якісного до кількісного оцінювання швидкості зміни температури на поверхні міокарда.

Метою дослідження є оцінювання провідності коронарних судин для дослідження кровоплину у поверхневому шарі міокарда під час зігрівання та охолодження серця в умовах штучного кровообігу.

Результати.Числове значення кількісного критерію отримано шляхом визначення різниці температур між кров'ю і міокардом, яке обчислюють як різницю геометричних площ під кривими розподілу температур у рівнянні температурного поля для постійного і поточного температурного напору. Метод контурування для визначення провідності коронарних судин дає змогу виділити ділянки на поверхні міокарда, в яких зміна температури значно відстає від середньої температури на поверхні під час зігрівання або охолодження серця, що уможливлює оцінювання стану дрібних коронарних судин в міокарді.

Ключові слова: математичне моделювання, алгоритм детектування Канні, температура серия, температурні профілі, гіпотермія, гіпертермія, штучний кровообіг. 
Шлькков В.B. ${ }^{l}$, канд.техн.наук, доцент, доцент кафедры биомедицинской инженерии

Киевского политехнического института им. Игоря Сикорского

e-mail: v.shlykov@kpi.ua

Максименко В.Б. ${ }^{2}$, д-р.мед.наук, професор,

Зам. директора по научной роботе

Киевского политехнического института им. Игоря Сикорского

e-mail: maksymenko.vitaliy@gmail.com

${ }^{1}$ Национальный технический университет Украины

"Киевский политехнический институт имени Игоря Сикорского"

пр. Победы, 37, Киев, Украина, 03056

${ }^{2}$ Национальный институт сердечно-сосудистой хирургии

имени М.М. Амосова

ул. Амосова, 6, Киев, Украина, 03038

\section{МЕТОД ОПРЕДЕЛЕНИЯ ПРОВОДИМОСТИ КОРОНАРНЫХ СОСУДОВ СРЕДСТВАМИ ТЕРМОГРАФИИ}

Введение. Для количественной оценки неравномерности распределения температуры на поверхности сердца предложен алгоритм расчета количественного критерия, который может являться объективным маркером эффективной защиты сердца и мозга. Метод определения проводимости коронарных сосудов реализован на основе алгоритма Канни для определения тепловых контуров, которые вычисляются по градиентам температурного поля на изображении сердца в инфракрасном спектре.

Целью исследования является оценка проводимости коронарных сосудов для исследования кровотока в поверхностном слое миокарда во время согревания и охлаждения сердца в условиях искусственного кровообращения.

Результаты. Получено числовое значение количественного критерия, который рассчитывается путем определения разницы температур между кровью и миокардом, что косвенно позволяет оценивать состояние мелких коронарных сосудов в миокарде.

Ключевые слова: математическое моделирование, температура сердиа, температурные профили, гипотермия, гипертермия, искусственное кровообращение. 